Відділі захворювань риб Національного науково-дослідного ветеринарного інституту в Пулавах (Польща). Матеріали для бактеріологічних досліджень були взяті від риб з видимими клінічними проявами захворювання. Найбільший діаметр зони пригнічення $(20,63 \pm 1,44$ мм) був відзначений щзодо росту Aeromonas sobria (K825), в той час, як найменший діаметр зони пригнічення $(13,38 \pm 0,42$ мм) $i$ (13,0 \pm 0,94мм) - відносно штамів Aeromonas hydrophila (K886) i Aeromonas salmonicida subsp. salmonicida (St30), відповідно. Етанольний екстракт листя F. vasta проявив помірну активність щчодо Aeromonas hydrophila $i$ Aeromonas salmonicida subsp. salmonicida (St30); в свою чергу, для Aeromonas sobria була характерна висока ступінь чутливості щьодо дї екстракту досліджуваної рослини. Надалі, при визначенні складу речовин, щзо надають антимікробну активність відносно Aeromonas, має бути зроблений фітохімічний скринінг листя F. vasta. Для оиінки балансу користь / ризик при використанні изих рослин в лікуванні Aeromonas-індукованих інфекиій в аквакультурі має бути здійснено дослідження in vivo. В даний час проводиться фракціонування, щуо спирається на результати визначення біоактивності сполук, щзо містяться в екстрактах, для ідентифікації сполук, відповідальних за ию активність.

Ключові слова: Ficus vasta, Aeromonas sobria, Aeromonas hydrophila, Aeromonas salmonicida subsp. salmonicida, антимікробна активність, дискодифузійний метод Байєра-Кірбі, етанольний екстракт

DOI 10.32900/2312-8402-2019-121-44-52

УДК 636.92.084.085.55:591.11

\title{
БІОХІМІЧНІ ПОКАЗНИКИ КРОВІ КРОЛІВ М'ЯСНОГО НАПРЯМУ ПРОДУКТИВНОСТІ ЗА ЗГОДОВУВАННЯ МАЛОКОМПОНЕНТНИХ КОМБІКОРМІВ
}

\author{
Аксьонов С. О. ${ }^{1}$ м. н. с. \\ Інститут тваринництва НААН України
}

В статті висвітлено результати експериментальних досліджень біохімічних показників крові кролів м'ясного напряму продуктивності, вирощених за різних умов годівлі.

Піддослідному молодняку згодовували малокомпонентні комбікорми, з різною структурою та співвідношенням компонентів. У розрізі трьох дослідних груп використовували екструдовані зернові компоненти, розбіжності між групами забезпечували шляхом зменшення частки ячменю з 70 \% до $50 \%$ за масою та відповідно збільшенням частки зерна сої. Вміст сінного борошна в раціонах усіх порівнювальних груп становив $10 \%$.

Встановлено, щзо біохімічні показники крові кролів дослідних груп знаходилися у межах фізіологічної норми.

Покращення рівня і повноцінності протеїнового живлення тварин, за рахунок підвищення частки сої у складі комбікорму кролів II і III груп на 10 і 20 \%, сприяло підвищенню загального рівня білка у сироватці крові. Так, у кролів ІІІ дос-

\footnotetext{
${ }^{1}$ Науковий керівник - д. с.-г. н., професор Помітун I. А.
} 
лідної групи вміст білка був вірогідно вищим у порівнянні з I та II - на 9,2513,52 г/л.

Виявлено чітку тендениію між збільшенням частки сої у складі комбікорму та зростанням у дослідних кролів вмісту сечовини у крові. Кролі ІІІ дослідної групи за цим показником перевищували ровесників II та I групи відповідно на $26,1 \% \operatorname{ma~} 46,8 \%$.

Встановлено, щчо сприятливіші щуодо мінерального складу умови годівлі, забезпечили більший вміст основних мікроелементів в сироватиі крові кролів третьої групи. За вмістом кальцію різниия між I і II групою вірогідна.

Слід вказати на суттеву різницю біохімічних показників крові між групами кролів, яких вирощували за різним співвідношенням складових ращіону. Підвищення обмінних прочесів спостерігалося в організмі кролів III дослідної групи, які отримували рачіон за структурою: ячменю - $50 \%$, сої - $40 \%$, сінного борошна -

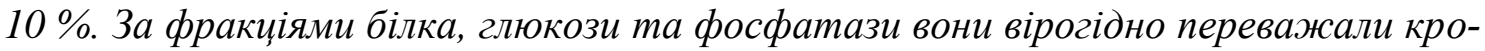
лів інших дослідних груп.

Ключові слова: біохімічні показники, відгодівля, кров, кролі, малокомпонентні комбікорми, молодняк, м'ясний напрям, продуктивність.

Кролятина вважається високоцінним дієтичним продуктом. Вона є джерелом повноцінного білку, мінеральних речовин і вітамінів. За вмістом азотистих речовин поступається тільки м'ясу індички.

Відомо, що склад крові є симптоматичним відображенням інтенсивності перебігу обмінних процесів, які протікають в організмі тварин під впливом певних кормових факторів [5]. Тому випробування різних кормів та добавок у раціонах тварин супроводжуються поглибленими дослідженнями крові.

Склад крові дозволяє спостерігати різні зміни, які відбуваються в організмі тварини під впливом годівлі та утримання, що дає можливість оцінити його загальний фізіологічний стан та рівень його пристосованості до умов середовища [3-5].

Біохімічний аналіз крові - сукупність методів лабораторної діагностики, які дозволяють оцінити роботу внутрішніх органів (печінка, нирки, підшлункова залоза та ін.), отримати інформацію про метаболізм (обмін ліпідів, білків, вуглеводів), з'ясувати потребу в мікроелементах. Стан крові віддзеркалює загальний стан організму тварини $[6,8]$.

Вивченню даної проблеми присвячені роботи О. В. Сауткина [9], Н. А. Черьоминої зі співавторами [11], Я. В. Лесик [7].

Загальна кількість крові у кроля - 32-67 см³ або 34-70 г. У спокійному стані у живого кроля четвертина всієї крові знаходиться в м'язах, інша четвертина у печінці, третина - в серці та крупних судинах [1].

Вікова динаміка біохімічних показників крові молодняку кролів у ранній період життя відображає становлення адаптаційно-компенсаторних процесів організму. Відомо, що кровотворні тканини характеризуються інтенсивними процесами проліферації, внаслідок чого вони легко піддаються дії стрес-факторів різної етіології [13].

Активну реакцію крові забезпечують буферні системи: карбонатна, фосфатна, гемоглобінна та білкова. Більш того, білкові фракції відіграють важливу роль в імунітеті, так як несуть у собі антитіла, які утворились на антиген, що потрапив в організм. 
Слід зазначити, що система кровообігу є найбільш чутливою до вмісту важких металів в організмі, однією з перших реагує на зміни в годівлі тварин і тим більше - зміну макро-, мікроелементного та вітамінного забезпечення організму. Найбільш поширеними дослідженнями щодо виявлення біологічної дії годівлі на організм $є$ вивчення коливань морфологічного і біохімічного складу крові тварин, тому, з огляду на іiї доступність і можливість повторного отримання без шкоди для здоров'я тварин, гематологічні дослідження мають важливе значення для вивчення інтенсивності обміну речовин в організмі $[10,12]$.

Мета досліджень - дослідити біохімічні показники крові кролів м'ясного напряму продуктивності, у зв'язку з різною структурою використовуваних для їх годівлі малокомпонентних комбікормів.

Матеріал та методи досліджень. Об'єктом досліджень були кролі м'ясного напряму продуктивності у віці 120 діб, яких утримували в умовах фізіологічного двору Інституту тваринництва НААН в закритому приміщенні з урахуванням мікроклімату, годівлі та напування. Застосовували сухий тип годівлі (малокомпонентні комбікорми) з різною структурою складників: зерно ячменю, сої та сінного борошна. Співвідношення компонентів комбікорму (\% за масою): I група: ячмінь - 70, соя - 20, сінне борошно - 10; II група: ячмінь - 60, соя - 30, сінне борошно - 10; III група: ячмінь -50 , соя -40 , сінне борошно -10 . Зернові корми були екструдованими. Згодовування комбікормів - із використанням бункерних годівниць. Напування - з чашкових напувалок.

Визначення загального білка, глюкози, креатиніну, загального кальцію, фосфору неорганічного, сечовини, активності аланінамінотрансферази (АлАТ), аспартатамінотрансферази (АсАТ), лужної фосфатази здійснювали в лабораторії молекулярно-генетичних та фізіолого-біохімічних досліджень в тваринництві Інституту тваринництва НААН.

Зразки крові для досліджень відбирали в серологічні пробірки з яремної вени до годівлі тварин перед їх забоєм. При взяті крові дотримувались правил асептики і антисептики. До лабораторії кров доставляли в день іiі взяття. Для більш повного відділення сироватки, пробірку з кров'ю обводили тонкою спицею 3 нержавіючої сталі та ставили в термостат при температурі $+37{ }^{\circ} \mathrm{C}$ на одну годину. Сироватку крові зливали у центрифужні пробірки та центрифугували 15 хвилин. Кількість зразків - по десять з кожної групи [2].

Результати досліджень. Вплив різних рівнів малокомпонентних комбікормів у раціонах кролів на білковий і вуглеводно-жировий обмін аналізували за показниками хімічного складу крові піддослідних кролів.

Було проведено хімічний аналіз досліджуваних малокомпонентних комбікормів. Результати аналізу свідчать, що у зв'язку зі зміною частки ячменю та сої у структурі комбікормів, завдяки збільшенню частки зерна сої простежувалося поступове підвищення частки сирого жиру у дослідних групах: у I групі цей показник становив $6,61 \%$, у II - 7,26 \% і в III - 8,54 \% відповідно.

Сира клітковина в комбікормі вкрай важлива, оскільки вона забезпечує правильне протікання процесу перетравлення їжі. При зменшенні частки ячменя у складі комбікормів відбувалося зменшення вмісту сирої клітковини - 5,04 \%, 4,33 \% і 4,34 \% відповідно по групах і підвищення сирого протеїну з 11,97 \% у першій групі до 13,93\% у третій.

Із збільшенням у структурі досліджуваних комбікормів зерна сої, вміст обмінної енергії збільшувався : I група - 11,64 МДж, II група - 11,94 МДж і III група - 12,13 МДж. 
Виходячи з хімічного складу малокомпонентних комбікормів, визначено їх загальну поживність в кормових одиницях: I група - 1,224 к. од., II група 1,283 к. од., III група - 1,313 к. од.

Результати впливу досліджуваних нами факторів годівлі на стан обміну речовин в організмі кролів наведено в (табл. 1).

Таблиия 1

Біохімічні показники сироватки крові кролів $(\mathrm{M} \pm \mathrm{m} ; \mathrm{n}=4)$

\begin{tabular}{|c|c|c|c|}
\hline \multirow{2}{*}{ Показник } & \multicolumn{3}{|c|}{ Групи } \\
\cline { 2 - 4 } & I & II & III \\
\hline Загальний білок, г/л & $48,00 \pm 7,04$ & $43,75 \pm 4,37$ & $57,25 \pm 5,41$ \\
\hline Глюкоза, ммоль/л & $4,28 \pm 0,32$ & $5,18 \pm 0,32$ & $6,50 \pm 0,54^{*}$ \\
\hline Креатинін, ммоль/л & $70,75 \pm 0,48$ & $73,00 \pm 0,58^{*}$ & $71,50 \pm 0,96$ \\
\hline
\end{tabular}

Примітка. * ${ }^{*} \leq 0,05$ - вірогідність різнииі щ⿻одо I групи

Біохімічні показники крові кролів дослідних груп знаходяться у межах фізіологічної норми. Разом з тим підвищення частки сої у складі комбікорму кролів III групи сприяло підвищенню загального рівня білка у сироватці крові, який свідчить про покращення рівня і повноцінності протеїнового живлення тварин. У кролів III дослідної групи вміст білка був вірогідно вищим у порівнянні з I та II на 9,25-13,52 г/л.

Рівень глюкози також мав тенденцію до підвищення в сироватці крові кролів II та III групи. Цей показник, свідчить про енергетичну регуляцію і метаболізм в організмі тварини та вказує на частки вуглеводних кормів у раціоні.

Кількість креатиніну в сироватці крові II дослідної групи достовірно підвищувався в порівнянні з іншими групами, що може свідчити як про збільшення альбумінів у крові тварин, так і про порушення виведення креатиніну нирками в результаті вазоренальної артеріальної гіпертензії у кроликів.

У кролів сечова кислота $є$ важливим продуктом метаболізму азотовмісних сполук (табл. 2).

Таблиия 2

\section{Активність АлАТ, АсАТ та вміст сечової кислоти у сироватці крові кролів (M $\pm \mathbf{m} ; \mathbf{n}=4)$}

\begin{tabular}{|c|c|c|c|}
\hline \multirow{2}{*}{ Показник } & \multicolumn{3}{|c|}{ Групи } \\
\cline { 2 - 4 } & I & II & III \\
\hline Сечовина, ммоль/л & $3,05 \pm 0,55$ & $3,55 \pm 0,26$ & $4,48 \pm 0,45$ \\
\hline АлАТ, од/л & $38,75 \pm 1,49$ & $43,75 \pm 0,63 *$ & $42,00 \pm 0,82$ \\
\hline АсАТ, од/л & $49,25 \pm 3,20$ & $56,00 \pm 0,82$ & $54,25 \pm 0,85$ \\
\hline
\end{tabular}

Примітка. *p $\leq 0,05$ - вірогідність різниці щзодо І групи

Дослідженнями встановлено, що збільшення частки сої у складі комбікорму у кролів III дослідної групи супроводжувалося зростанням вмісту сечовини. За цим показником вони перевищували ровесників II та I групи відповідно на 26,1 \% та 46,8 \%. Кролі II групи переважали також тварин I групи на 16,3%. Разом 3 тим, різниця між групами виявилася не вірогідною, однак встановлена тенденція є досить чіткою. 
Проаналізувавши активність ферментів АлАТ та АсAT можна зробити висновок, що згодовування кормів не справляє негативного впливу на функціональний стан печінки у кролів, а навпаки покращує його.

Дослідженнями вмісту основних мікроелементів в сироватці крові встановлено (табл. 3), що за вмістом кальцію різниця між I і II групою виявилась достовірною. За вмістом фосфатази різниця склала 6,9 \% та 7,9 \% відповідно. Концентрація неорганічного фосфору у сироватці крові підвищується при надлишку його у раціоні, передозуванні вітаміну D та зниженні активності щитоподібних залоз при гломерулонефриті, нефротичному синдромі. Лужна фосфатаза служить індикатором, за яким можна судити про клітинну проникність, регуляцію жирового i білкового обмінів, а також засвоюваність мінеральних речовин з крові тканинами. При підвищенні рівня лужної фосфатази в третій групі на 6,9\%, рівень АсАТ зріз на 10,1 \%. Вираженість тенденції в динаміці рівня лужної фосфатази і АсАТ, свідчить про підвищення процесів всмоктування речовин з крові в тканини. Це вказує на більш сприятливі щодо мінерального складу, умови годівлі третьої групи кролів.

Виходячи з вищевикладеного, слід вказати на суттєву різницю біохімічних показників крові між групами кролів, яких вирощували за різним співвідношенням складових раціону.

Таблиия 3

\section{Концентрація Кальцію, Фосфору та Фосфатази у сироватці крові

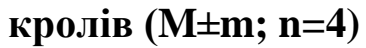

\begin{tabular}{|c|c|c|c|}
\hline \multirow{2}{*}{ Показник } & \multicolumn{3}{|c|}{ Групи } \\
\hline & I & II & III \\
\hline Кальцій загальний, ммоль/л & $3,00 \pm 0,18^{*}$ & $2,15 \pm 0,09$ & $2,55 \pm 0,24$ \\
\hline Фосфор неорганічний, ммоль/л & $1,73 \pm 0,03$ & $1,95 \pm 0,17$ & $1,90 \pm 0,26$ \\
\hline Фосфатаза лужна, од/л & $79,25 \pm 3,07$ & $78,50 \pm 1,66$ & $84,75 \pm 0,95 * *$ \\
\hline
\end{tabular}

У наших дослідженнях встановлена вірогідна різниця за фракціями білка, глюкози, кальцію та фосфору між кролями, яких вирощували за третім варіантом годівлі та тваринами, вирощеними за інших дослідних варіантів годівлі. Підвищення обмінних процесів спостерігається в організмі кролів III дослідної групи.

\section{Висновки:}

1. Результати досліджень крові свідчать про нормальний перебіг біохімічних процесів у організмі кролів усіх груп, які перебували в межах фізіологічної норми.

2. Різниця між ровесниками за біохімічними показниками сироватки крові (білка - 13,5 г/л; глюкози - 1,32 ммоль/л; сечовини - 0,93 ммоль/л; кальція - 0,4 ммоль/л; фосфатази - 6,25 од/л), вказує на підвищений перебіг обмінних процесів у організмі тварин II і III груп, що $є$ наслідком зміни структури зернових компонентів у складі комбікорму у бік збільшення вмісту екструдованої сої.

3. Найбільш ефективною виявилась III дослідна група, в якій біохімічні показники крові: білка - 23,6 \%; глюкози - 34,2 \%; сечовини - 32,0 \%; фосфатаза $-6,5 \%$ були вищими порівняно з групами. 


\section{Бібліографічний список}

1. Бащенко М. І. Кролівництво / М. І. Бащенко, О. Ф. Гончар, С. А. Шевченко. - 3-є вид. перероб. - Чернобаївське КПП, 2018. - С. 40.

2. Влізло В. В. Лабораторні методи досліджень у біології, тваринництві та ветеринарній медицині : довідник / В. В. Влізло, Р. С. Федорук, І. Б. Ратич; за ред. В. В. Влізла. - Львів : СПОЛОМ, 2012. С. - 53.

3. Коцюбенко А. А. Морфологические и биохимические показатели крови кроликов, выращенных по разным технологиям / А. А. Коцюбенко // Вестник Новосибирского государственного аграрного университета. - Новосибирск, 2013. №1 (26). С. 57-61.

4. Коцюбенко Г. А. Морфологічні та біохімічні показники крові кролів різних генотипів / Г. А. Коцюбенко // Збірник наукових праць Вінницького національного аграрного університету. - 2012. - вип. 5 (67). - С. 125-128.

5. Коцюбенко Г. А. Науково-практичні методи підвищення продуктивності кролів: монографія / Г. А. Коцюбенко. - Миколаїв: МНАУ, 2013. - С. 122.

6. Кучерявий В. П. Морфологічні та біохімічні показники крові відгодівельного молодняку кролів / В. П. Кучерявий, О. Б. Штенська, Ю. І. Ванжула // Науковий вісник Львівського національного університету ветеринарної медицини та біотехнологій ім. С. 3. Гжицького. - Львів, 2016. - Т. 18, № 2 (67). - С. 126.

7. Лесик Я. В. Фізіолого-біохімічні процеси в організмі і продуктивність кролів залежно від умов годівлі та утримання. автореф. дис. на здобуття наукового ступеня кандидата вет. наук : спец. 03.00.13 «Фізіологія людини і тварин»/ Я. В. Лесик. - Львів, 2008. - 20 с.

8. Медведева М. Клиническая ветеринарная лабораторная диагностика. Москва : Аквариум-Плюс, 2008. - С. 35

9. Сауткин А. В. Ветеринарно-санитарная оценка мяса кроликов при использовании препарата «Эмисел» : автореф. дисс. на соискание ученой степени канд. биол. наук: спец. 06.02.05. «Ветеринарная санитария, экология, зоогигиена и ветеринарно-санитарная экспертиза» / А. С. Сауткин. - Москва, 2010. - 24 с.

10. Хруцький С. С. Зміни морфологічного і біохімічного складу крові корів за впливу екологічних чинників / С. С. Хруцький, О. М. Маменко // Проблеми зооінженерії та ветеринарної медицини: Зб. наук. пр. / Харківської державної зооветеринарної академії. - Харків : РВВ ХДЗВА, 2013. - вип. 27, 1 - С. 229

11. Черёмина Н. А. Лейкоцитарная формула и ее значение для клиник: методические рекомендации / Н. А. Черёмина, К. С. Сидорова, О. А. Драгич, С. А. Пашаян, Т. В. Качалкова, Н. Г. Бобкова, Е. А. Чудинова, В. М. Толстая. Тюмень, 2009. - С. 39

12. Шакула А. А. Влияние стимулятора роста СХ на морфологические показатели крови и состояние углеводно-жирового обмена бычков / А. А. Шакула // Проблеми зооінженерії та ветеринарної медицини : зб. наук. пр. / Харків/ держ. зоовет. академії. - Харків : РВВ ХДЗВА, 2009. - Вип. 18, ч. 1. - С. 338

13. Xiccato G. Reproductive rhythm and litter weaning age as they affect rabbit doe performance and body energy balance / G. Xiccato, A. Trocino, C. Boiti, G. Brecchia // Anim. Sci. - 2005. - Vol. 81. - P. 289-296. 


\section{References}

1. Bashchenko, M. I., \& Honchar, O. F.,. Shevchenko, Ye. A. (2018). Krolivnytstvo - Rabbit breeding. Cherkasy : Chernobaivske KPP [in Ukrainian].

2. Vlizlo, V. V., Fedoruk, R. S., Ratych, I. B. (2012). Laboratorni metody doslidzhen u biolohii, tvarynnytstvi ta veterynarnii medytsyni [Laboratory methods of research in biology, livestock and veterinary medicine] Lviv: SPOLOM [in Ukrainian].

3. Kocjubenko, A. A. (2013). Morfologicheskie i biohimicheskie pokazateli krovi krolikov, vyrashhennyh po raznym tehnologijam [Morphological and biochemical blood parameters of rabbits grown by different technologies]. Novosibirsk : NGAU [in Russia].

4. Kotsiubenko, H. A. (2012). Morfolohichni ta biokhimichni pokaznyky krovi kroliv riznykh henotypiv [Morphological and biochemical parameters of blood of rabbits of different genotypes]. Vinnytsa : VNAU [in Ukrainian].

5. Kotsiubenko, H. A. (2013). Naukovo-praktychni metody pidvyshchennia produktyvnosti kroliv [Scientific and practical methods for increasing the productivity of rabbits]. Mykolaiv : MNAU [in Ukrainian].

6. Kucheriavyi, V. P., \& Shtenska, O. B., Vanzhula Yu. I. (2016). Morfolohichni ta biokhimichni pokaznyky krovi vidhodivelnoho molodniaku kroliv [Morphological and biochemical parameters of blood of fattening young rabbits]. Naukovy`j visny`k L'vivs kogo nacional’nogo universy tetu vetery`narnoyi medy`cy`ny ta biotexnologij imeni S. Z. G`zhy`cz'kogo. - Scientific herald of the Lviv National University of Veterinary Medicine and Biotechnology named after S.Z.Gzhytsky, 18, 2 (67), 126 [in Ukrainian].

7. Lesyk, Ya. V. (2008). Fizioloho-biokhimichni protsesy v orhanizmi i produktyvnist kroliv zalezhno vid umov hodivli ta utrymannia [Physiological and biochemical processes in the organism and productivity of rabbits depending on the conditions of feeding and maintenance]. Extended abstract of candidate's thesis. Lviv [in Ukrainian].

8. Medvedeva, M. (2008). Klinicheskaja veterinarnaja laboratornaja diagnostika [Clinical veterinary laboratory diagnostic]. Moskva : Akvarium-Pljus. [in Russia].

9. Sautkin, A. V. (2010). Veterinarno-sanitarnaja ocenka mjasa krolikov pri ispol'zovanii preparata «Jemisel» [Veterinary-sanitary assessment of rabbit meat when using the drug «Emisel»]. Extended abstract of candidate`s thesis. Moskva [in Russia].

10. Khrutskyi, S. S., \& Mamenko, O. M. (2013). Zminy morfolohichnoho i biokhimichnoho skladu krovi koriv za vplyvu ekolohichnykh chynnykiv [Changes in morphological and biochemical composition of blood of cows under the influence of environmental factors]. Problemy zooinzhenerii ta veterynarnoi medytsyny - Problems of zoinengineering and veterinary medicine. Kharkiv, 27, 1, 229 [in Ukrainian].

11. Cherjomina, N. A., \& Sidorova, K. S., Dragich, O. A., Pashajan, S. A., Kachalkova, T. V., Bobkova, N. G., (2009). Lejkocitarnaja formula i ee znachenie dlja klinik [Leukocyte formula and its value for clinics]. Tjumen', [in Russia].

12. Shakula, A. A. (2009). Vlijanie stimuljatora rosta SH na morfologicheskie pokazateli krovi i sostojanie uglevodno-zhirovogo obmena bychkov [The effect of CX growth stimulant on the morphological parameters of blood and the state of carbohydrate-fat metabolism of bulls]. Problemy zooinzhenerii ta veterynarnoi medytsyny Problems of zoinengineering and veterinary medicine/ Kharkiv, 18, 1, 338 [in Ukrainian]. 
13. Xiccato G., \& Trocino A., Boiti C., Brecchia G. (2005). Reproductive rhythm and litter weaning age as they affect rabbit doe performance and body energy balance. Animal Science, 81. P. 289-296.

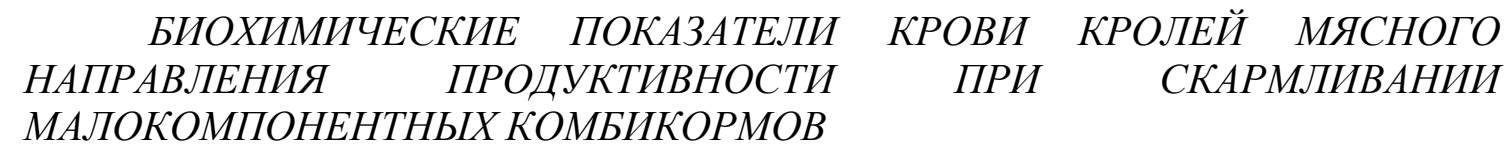

Аксёнов Е. А., Институт животноводства НААН

В статье освещены результаты экспериментальных исследований биохимических показателей крови кролей мясного направления продуктивности, выращенных при разных условиях кормления.

Подопытному молодняку скармливали малокомпонентные комбикорма, $c$ различной структурой и соотношением компонентов. В разрезе трех опытных групп использовали экстрадированные зерновые компоненты, различия между группами обеспечивали путем уменьшения доли ячменя с $70 \%$ до $50 \%$ по массе $u$, соответственно, увеличения доли зерна сои. Содержание сенной муки в рационах всех сравниваемых групп составляло $10 \%$.

Установлено, что биохимические показатели крови кроликов опытных групп находились в пределах физиологической нормы.

Улучшение уровня и полноценности протеинового питания животных, за счет повышения доли сои в составе комбикорма кроликов II и III групп на 10 и $20 \%$ способствовало повышению общего уровня белка в сыворотке крови. Так у кролей III опытной группы содержание белка было достоверно выше по сравнению с первой и второй - на 9,27-13,52 г / л.

Выявлено четкую тенденичию между увеличением удельного веса сои в составе комбикормов и увеличением у опытных кроликов содержания мочевины в крови. Кролики III опытной группь по этому показателю превышали ровесников II и І группь соответственно на 26,1\% и 46,8\%.

Установлено, что благоприятные по минеральному составу условия кормления обеспечили больщее содержание основных микроэлементов в сыворотке крови кролей третьей группь. По содержанию кальциия разница между I и II группой достоверна.

Следует указать на существенную разнииу биохимических показателей крови между группами кролей, выращиваемых с разным соотношением составляюших ращиона. Повышение обменных процессов наблюдалось в организме кроликов III опытной группь, получавшей рачион по структуре: ячменя - 50\%, сои$40 \%$, сенной муки - $10 \%$. По фракциям белка, глюкозы, фосфатазы они достоверно превышали кроликов других опытных групп.

Ключевые слова: биохимические показатели, откорм, кровь, кролики, малокомпонентные комбикорма, корма, молодняк, мясное направление, продуктивность.

\section{BIOCHEMICAL INDICATORS OF BLOOD OF RABBITS OF MEAT'S AT LOW-COMPONENT FEEDING}

Aksyonov E. A., Institute of Animal Science

The article highlights the results of experimental studies of hematological and biochemical blood parameters of rabbits, of meat direction of productivity, under different feeding conditions.

The that experimental young animals were feeding by low-compound feed with a different structure and ratio of components. The extruded grain components for the 
three research groups were used. The disagreements between groups were by reducing the share of barley from $70 \%$ to $50 \%$ by weight and the corresponding increasing provided of soybeans proportion. The content of hay meal in rations of all comparative groups was $10 \%$.

It was established that the biochemical parameters of blood of research groups rabbits were within the limits of the physiological norm.

The improvement of the level and quality of protein nutrition of animals, by increasing the proportion of soy in the feed compo of II and III rabbits groups by 10 and $20 \%$, contributed the increase of the total protein level in the blood serum. Thus, for rabbits of the IIIrd experimental group, the protein content was significantly higher in comparison with the first and second ones - at 9,25-13,52 $\mathrm{g} / \mathrm{l}$.

A clear tendency was revealed between the increase of soybean proportion in the composition of feeds and the increase of blod urea in experimental rabbits. Rabbits of the III experimental group on this indicator were exceeded their peers of the II and I groups, respectively, by $26,1 \%$ and $46,8 \%$.

It was found that favorable in mineral composition feeding conditions, provided a higher content of basic trace elements in the serum of rabbits of the third group. In terms of calcium content, the difference between the I and II group is significant.

It is necessary to point out the significant difference in the biochemical blood parameters between the groups of rabbits with different ratios of the ration components. The increase of metabolic processes is observed in the body of rabbits of the IIIrd experimental group with a diet according to the structure: barley-50\%, soy-40\%, hay flour $-10 \%$. In fractions of protein, glucose, phosphotase, they significantly exceeded the rabbits of other experimental groups.

Key words: biochemical parameters, fattening, blood, rabbits, low-component compound feed, feed, young animals, meat and skin direction, productivity.

DOI 10.32900/2312-8402-2019-121-52-60

УДК 636.2.053.083

\title{
ВДОСКОНАЛЕННЯ ТЕХНОЛОГІЧНОГО РІШЕННЯ ЕЛЕМЕНТУ ВИРОЩУВАННЯ ТЕЛИЧОК МОЛОЗИВНО-ПРОФІЛАКТОРНОГО ПЕРІОДУ
}

\author{
Антоненко С. Ф. к. с.-Г. Н., ст. Н. с. \\ Інститут тваринництва НААН
}

У статті наведено результати дослідження по удосконаленню технологічних рімень вирощування теличок української чорно-рябої молочної породи в молозивно-профілакторний період в ДП ДГ «Гонтарівка» Інстититу тваринниитва НААН Вовчанского району Харківській області. При вивченні та обгрунтуванні параметрів основних технологічних рішень, при вирощуванні теличок молозивнопрофілакторного періоду було сформовано дві групи теличок по 5 голів у кожній. Першу групу утримували в клітках вольєрах (дослідна група), друга - групових секиіях. Було проведено п'ять науково-господарських дослідів протягом 10 діб кожного.

Площа клітки - вольєра становила $1 \mathrm{M}^{2}$. Термін утримання телят у молозивно-профілакторний період - 10 діб. В клітках розміром 1 м $\times 1$ м встановлювали фіксатором для утримання пляшки з соскою з молозивом і молоком. 